\title{
Effect of Health Education on Women's Knowledge Level about Pap Smear's Early Detection of Cervical Cancer Prevention
}

\author{
Rostime Hermayerni Simanullang ${ }^{1}$ Selli Dosrina Sitopu² \\ ${ }^{1}$ Sekolah Tinggi Ilmu Kesehatan Murni Teguh, Medan, \\ North Sumatra, Indonesia \\ ${ }^{2}$ Nursing Faculty of Darma Agung University, North Sumatra, \\ Indonesia

\begin{abstract}
Address for correspondence Rostime Hermayerni Simanullang, S.Kep., Ns., M.Kes, Sekolah Tinggi Ilmu Kesehatan Murni Teguh Medan, Jl. Kapten Batu Sihombing, Medan Estate, Kec. Percut Sei Tuan, Kabupaten Deli Serdang, Sumatera Utara, Deli Serdang 20371, Indonesia (e-mail: hermayerni@gmail.com).
\end{abstract}

Asian J Oncol 2020;6:65-71

\begin{abstract}
Keywords

- health education

- pap smear

- cervical cancer

- knowledge of women

Cervical cancer is a scary disease for women all over the world. This disease can actually be prevented and identified early. Pap smear is one of the tools of early detection to determine the presence of symptoms of cervical cancer. If women's knowledge is good about pap smear's early detection of cervical cancer, it can prevent the disease. The objective of this study was to know the effect of health education in women about pap smear which aids in early detection and prevention of cervical cancer. This was a quasi-experimental one group pretest, conducted without a control group at Murni Teguh Memorial Hospital (MTMH), Medan, North Sumatra from June to July 2018. There were 36 samples selected using purposive sampling. Wilcoxon signed-rank test was used for data analysis. The results of this study showed that there was a difference in the mean value of women's knowledge levels $(p=0.000)$ before and after the intervention. The conclusion of this study was that there was a significant effect of health education in terms of an increase in the level of women's knowledge about pap smear's early detection and prevention of cervical cancer. It is expected that health education about pap smear's early detection and prevention of cervical cancer will prove to be very important in the future.
\end{abstract}

\section{Introduction}

Cervical cancer is a malignant tumor growing inside the neck of the uterine/cervix of the lowest part of the uterine which sticks on the branch at the top of the vagina. The cancer has surpassed heart disease as the top cause of death for Hispanics in the United States; therefore, it is even more critical to focus on early detection of cancer in this population. ${ }^{1}$ Cervical cancer usually attacks elderly women between 35 to 55 years of age. ${ }^{2}$ A very high percentage $(80-90 \%)$ of cervical cancer cases originate from squamous, which can cause death among women. ${ }^{3}$

The prevalence of cervical cancer is high in the member states of the European Union (EU), with approximately 34,000 new cases of cervical cancer and 13,000 annual deaths. ${ }^{4}$ The prevalence of cervical cancer is particularly high. These conclusions are drawn based on the highest rates in Romania and Lithuania (13.7/100,000 and $10.0 / 100,000$, respectively) and the lowest rate in Finland $(1.1 / 100,000){ }^{1}$

According to the Globocon data in 2018, new cases of cervical cancer in Indonesia reached 32,469 people. Tribun news reported that mortality due to cervical cancer has reached 18,279 per year. This means that approximately 50 Indonesian women died because of cervical cancer. The number has increased if one were to compare this to the Globocon data which states that in 2012, 26 Indonesian women died because of cervical. The latest Globocon data aligned with the research in Indonesia detected the occurrence of cervical cancer in 1 out of 1,000 women and an average of approximately 40 to 60 women died within a day. ${ }^{5}$
DOI https://doi.org/ 10.1055/s-0040-1709365 ISSN 2454-6798.
License terms

(1) (1) $\Theta \circledast$ 
Public knowledge about the pap smear's early detection and prevention of cervical cancer is still low and health promotion is required to improve their familiarity about the disease. $^{6}$

Therefore, the socialization of pap smear's early detection and prevention of cervical cancer is very necessary to change the behavior of the women in maintaining their health, especially their reproductive organs. Cervical cancer can mostly be prevented, namely, by avoiding risk factors, screening or early detection, and treating with human papillomavirus (HPV) vaccination to reduce mortality. ${ }^{3}$ Although the cervical cytology screening benefits a lot in the early diagnosis and treatment, cervical cancer outcomes vary significantly. ${ }^{7}$

In an effort to improve the health of the community, the program of the Department of Health, through health centers, is currently increasing the emphasis on promotion and preventive efforts. In this case, it is important to engage in the prevention of diseases such as cervical cancer, as it can be prevented with an early detection. Therefore, providing socialization and screening tests for timely detection is very important. One of the objectives of the prevention of cervical cancer is to decrease women's mortality rate. For this purpose, information needs to be disseminated amongst them about the pap smear's ability to detect and prevent cervical cancer. ${ }^{8}$ Pap smear is an examination of the state of the cells on the cervix (neck of the womb) and vagina. This examination is recommended to be done periodically for women who already had sexual intercourse, in addition to assessing the health of the female organs at the cellular level, and detecting cervical cancer at an early stage. ${ }^{9}$ In some countries, where detection of cervical cancer has been carried out early, there has been a decrease in the mortality of women. In the United States, women between 21 and 65 years do a pap smear thrice a year, and those between 30 and 65 years do a combination of pap smear and HIV every 5 years. ${ }^{10}$

Based on the assumption of researchers, one can be certain that most of women are not aware of the signs and symptoms of cervical cancer early, and the average woman who is visiting the hospital is often already up to the second stage and sometimes, the next stage. If a woman is aware about the purpose of pap smear, it is likely that she will know more about the early detection and prevention of cervical cancer.

\section{Materials and Methods}

\section{Participants}

The design used in this study was a pre-experimental study with pretest-posts and without a control group. The ShapiroWilk test was used because the data distribution was not normal, so the nonparametric test was used. The score before intervention was 0.043 and after intervention was 0.00 . The Wilcoxon signed-rank test was used to analyze the data in this study. This research was conducted at the Gynecology and Obstetrics Oncology unit of the MTMH, from June to July 2018. The population is whole subjects of the research. ${ }^{11}$ The population in this study was 122 women, who were visiting the Gynecology and Obstetrics Oncology unit of the MTMH, from June to July 2018, taking the number of subjects, following the Nursalam theory, as $30 \%$ of the total population. Subjects in this study were 36 samples of women selected using the purposive sampling technique. ${ }^{11}$ The inclusion criteria comprised the women who visited the Gynecology and Oncology unit of MTMH, between 35 to 55 years of age, had good communication skills, conscious, married, willing to be respondents, and understood the Indonesian language. The exclusion criteria included the women who had not visited the Gynecology and Obstetrics Oncology unit of the $\mathrm{MTMH}$, did understand the Indonesian language, were not willing to be responsive, aged below 35 years and above 55 years, and unmarried. This research was approved by The Ethics Committee of The Research, Nursing Faculty of North Sumatra University, No: 1948/IV/SP/2018.

\section{Outcome Measures}

The questionnaire used in this study was designed by Batas and Nursanti to measure women's knowledge about the pap smear's ability to detect and prevent cervical cancer at an early stage. The instrument passed the validity and reliability tests by previous researchers. The questionnaire was divided into two parts, identity of the respondents and questions consisting of 20 statements using multiple choice questions, with a total score of $20 .{ }^{12,13}$ The scores of respondents were converted into three categories: good (16-20), enough (12-15), and less. ${ }^{11}$

\section{Procedure}

Before disseminating health education, the participants were asked to complete personal data form including their characteristics. Participants signed an informed consent for those who were willing to be respondents. Thereafter, the researcher explained to the women about the purpose of assessing women's knowledge about the detection and prevention of cervical cancer that had been used by previous researchers. ${ }^{12,13}$ Then, questionnaires were distributed to respondents for measuring the level of knowledge of women before intervention. Following it, the researcher, assisted by a enumerator, conducted a session about pap smear's ability to detect and prevent cervical cancer over 30 minutes. The educational materials provided was about the meaning of cervical cancer, signs and symptoms, causes, risk factors, meaning and purpose of pap smear, how to prepare oneself before doing pap smear, and suggestions on how to perform a pap smear to detect and prevent cervical cancer early. 9,14,15 Media have been used in this study in the form of pictures and brochures containing graphic presentations of cervical cancer and pap smear. Thereafter, the researcher distributed the same questionnaires to the respondents to measure the level of knowledge among the women postintervention.

The study was carried out from the 25th of June to the 7th of July, 2018, from around 08.30 WIB to 11.30 WIB am at the Gynecology and Obstetrics Oncology unit of the MTMH. The reason for choosing this institution had to do with the fact that it was a referral hospital of cancer at North Sumatra, and the diagnostic tools here were complete and adequate. 


\section{Data Analysis}

SPPS version 22 was used for analyzing the data. Wilcoxon signed-rank test analysis along with $95 \%$ confidential interval $(\mathrm{CI})$ were used to determine the impact of health education on the level of awareness among women about pap smear's ability to detect and prevent cervical cancer prevention. The analysis results showed that $p$-value $<0.05$, which meant there was significant correlation between both variables. ${ }^{11}$

\section{Results}

The distribution of respondents across age groups was as follows: 51 to 55 years (36.1\%), 46 to 50 years (27.8\%), 41 to 45 year (22.2\%), and 35 to 40 years (13.3\%). The majority of respondents, based on educational background, attended high school (58.3\%), followed by college (25\%), junior school (16.7\%), and elementary school (0\%). Variables were measured based on age, education, and occupation are outlined in - Table 1.

- Table 2 shows that respondents' knowledge before health education in the age range of 35 to 40 years either did not exist, enough for four people (80\%), and less for one person (1\%). The substantial knowledge of respondents in the age range of 41 to 45 years was absent, most for two people (25\%), and less for six people (75\%). The knowledge of respondents in the age range of 46 to 50 years either did not exist, enough for six people (67.7\%) and less than four people (33.3\%). The knowledge of respondents in the age range of 51 to 55 years revealed the good knowledge of one person (7.1\%), enough for five people (35.7\%), and less for seven people $(50 \%)$. However, after health education, the knowledge of respondents improved significantly. The knowledge of women in the age range of 35 to 40 years was good for five people (100\%), enough and less for nobody. The knowledge of respondents in the age range of 41 to 45 years was good for five people (100\%), enough and less for nobody. The knowledge of respondents in the age range 46 to 50 years was good for eight people (100\%), enough and less for nobody. The knowledge of respondents in the age range of 51 to 55 years was good for eight people (80\%), enough for two people (20\%), and less for nobody.

- Table 3 shows the respondents' knowledge by education levels. The knowledge of respondents who attended junior school either did not exist, enough for two people (33.3\%), and less for four people (67.7\%). The knowledge of respondents who attended high school was good for one person (4.76\%), enough for 11 people (52.4\%), and less for nine people (42.9\%). The knowledge of respondents who attended college either did not exist, enough for seven people (77.8\%), and less for two people (22.2\%). However, after health education, there was a change in the level of knowledge of respondents at the level of junior school attendants: good for six people (100\%), enough and less for nobody. The knowledge of respondents at the high school was good for 21 people (100\%), enough and less for nobody. The knowledge of respondents at the bachelor's level was good for nine people (100\%).

- Table 4 shows that knowledge, based on occupation before the health education, of housewife respondents was good for one person (5\%), enough for ten people (50\%), and less for nine people (45\%). The knowledge of farmers in terms of good and enough was for nobody, and less for one person (100\%). The knowledge of respondents as employees was nothing for good, enough for nine people (62.9\%), and less for four people (30.8\%). The knowledge of self-employed respondents in terms of good and enough was for nobody and less for two people (100\%). However, after health education, the overall knowledge level of women turned out to be good, namely, knowledge of the female respondents as a housewives was good for 20 people (100\%), enough and less for nobody. The knowledge of

Table 1 Characteristics of respondent $(N=36)$

\begin{tabular}{|c|c|c|c|}
\hline S. no. & Characteristics & Frequency (f) & Percentage (\%) \\
\hline \multicolumn{4}{|c|}{ Age (y) } \\
\hline 1. & $35-40$ & 5 & 13.9 \\
\hline 2. & $41-45$ & 8 & 22.2 \\
\hline 3. & $46-50$ & 10 & 27.8 \\
\hline 4. & $51-55$ & 13 & 36.1 \\
\hline \multicolumn{4}{|c|}{ Education } \\
\hline 1. & Elementary & 0 & \\
\hline 2. & Junior school & 6 & 16.7 \\
\hline 3. & High school & 21 & 58.3 \\
\hline 4. & Graduation & 9 & 25 \\
\hline \multicolumn{4}{|c|}{ Occupation } \\
\hline 1. & Housewife & 20 & 55.6 \\
\hline 2. & Farmers & 1 & 2.8 \\
\hline 3. & Employees & 13 & 36.1 \\
\hline 4. & Self-employed & 2 & 5.6 \\
\hline
\end{tabular}


Table 2 Frequency distribution of respondents' knowledge about pap smear's early detection of cervical cancer prevention based on age $(N=36)$

\begin{tabular}{|c|c|c|c|c|c|c|c|c|}
\hline \multicolumn{9}{|c|}{ The level of women's knowledge (before) } \\
\hline \multirow[t]{2}{*}{ Age (y) } & \multicolumn{2}{|l|}{ Good } & \multicolumn{2}{|l|}{ Enough } & \multicolumn{2}{|l|}{ Less } & \multicolumn{2}{|l|}{ Total } \\
\hline & Frequency (f) & $\%$ & Frequency $(\mathrm{f})$ & $\%$ & Frequency (f) & $\%$ & Frequency (f) & $\%$ \\
\hline $35-40$ & & - & 4 & 80.0 & 1 & 20.0 & 5 & 13.9 \\
\hline $41-45$ & & - & 2 & 25.0 & 6 & 75.0 & 8 & 22.2 \\
\hline $46-50$ & & - & 6 & 66.7 & 4 & 44.4 & 10 & 27.8 \\
\hline $51-55$ & 1 & 7.1 & 5 & 35.7 & 7 & 50.0 & 13 & 36.1 \\
\hline \multicolumn{9}{|c|}{ The level of women's knowledge (after) } \\
\hline \multirow[t]{2}{*}{ Age (y) } & \multicolumn{2}{|l|}{ Good } & \multicolumn{2}{|l|}{ Enough } & \multicolumn{2}{|l|}{ Less } & \multicolumn{2}{|l|}{ Total } \\
\hline & Frequency (f) & $\%$ & Frequency $(\mathrm{f})$ & $\%$ & Frequency (f) & $\%$ & Frequency (f) & $\%$ \\
\hline $35-40$ & 5 & 100.0 & & & & - & 5 & 13.9 \\
\hline $41-45$ & 8 & 100.0 & & & & - & 8 & 22.2 \\
\hline $46-50$ & 8 & 80.0 & & & 2 & 20.0 & 10 & 27.8 \\
\hline 51-55 & 7 & 50.0 & 6 & & & - & 13 & 36.1 \\
\hline
\end{tabular}

Table 3 Frequency distribution of the respondents' knowledge about pap smear's early detection of cervical cancer prevention based on education $(N=36)$

\begin{tabular}{|c|c|c|c|c|c|c|c|c|}
\hline \multicolumn{9}{|c|}{ The level of women's knowledge (before) } \\
\hline \multirow[t]{2}{*}{ Education } & \multicolumn{2}{|l|}{ Good } & \multicolumn{2}{|l|}{ Enough } & \multicolumn{2}{|l|}{ Less } & \multicolumn{2}{|l|}{ Total } \\
\hline & Frequency (f) & $\%$ & Frequency (f) & $\%$ & Frequency (f) & $\%$ & Frequency (f) & $\%$ \\
\hline Elementary & & & & & & & 0 & \\
\hline Junior school & & & 2 & & 4 & & 6 & \\
\hline High school & 1 & & 11 & & 9 & & 21 & \\
\hline Bachelor & & & 7 & & 2 & & 9 & \\
\hline Total & 1 & & 20 & & 15 & & 36 & 100.0 \\
\hline \multicolumn{9}{|c|}{ The level of women's knowledge (after) } \\
\hline \multirow[t]{2}{*}{ Education } & \multicolumn{2}{|l|}{ Good } & \multicolumn{2}{|l|}{ Enough } & \multicolumn{2}{|l|}{ Less } & \multicolumn{2}{|l|}{ Total } \\
\hline & Frequency (f) & $\%$ & Frequency (f) & $\%$ & Frequency (f) & $\%$ & Frequency (f) & $\%$ \\
\hline Elementary & & & & & & & 0 & \\
\hline Junior school & 6 & 100 & & & & & 6 & \\
\hline High school & 21 & 100 & & & & & 21 & \\
\hline Bachelor & 9 & 100 & & & & & 9 & \\
\hline Total & 36 & & - & & - & & 36 & 100.0 \\
\hline
\end{tabular}

the respondent women as farmers was good for one person (100\%), enough and less for nobody. The knowledge of respondents as employees was good for 13 people (100\%), enough and less for nobody. The knowledge of respondents as self-employed was good for two people (100\%), enough and less for nobody.

Based on - Table 5, the results of the test using statistical analysis Wilcoxon Signed-rank test showed that $p$ value $<0.05$, where $p$ value $=0.00$. It can be concluded that there has been a significant influence of health education on the level of knowledge in women about pap smear's early detection and prevention of cervical cancer.

\section{Discussion and Conclusion}

This study was conducted to prove the influence of health education on the level of women's knowledge about pap smear's early detection of cervical cancer and prevention. The findings in this study revealed that there was a significant increase of knowledge level among women about pap smear's ability to detect and prevent cervical cancer after intervention $(p<0.05)$. The expected results of health education change human behavior, maintain and improve the health, or target the promotion of health. ${ }^{11}$ In this study, it was found that there was a significant influence on increasing 
Table 4 Frequency distribution of respondents' knowledge about the pap smear's early detection of cervical cancer prevention based on occupation $(N=36)$

\begin{tabular}{|c|c|c|c|c|c|c|c|c|}
\hline \multicolumn{9}{|c|}{ The level of women's knowledge (before) } \\
\hline \multirow[t]{2}{*}{ Occupation } & \multicolumn{2}{|l|}{ Good } & \multicolumn{2}{|l|}{ Enough } & \multicolumn{2}{|l|}{ Less } & \multicolumn{2}{|l|}{ Total } \\
\hline & Frequency (f) & $\%$ & Frequency (f) & $\%$ & Frequency (f) & $\%$ & Frequency (f) & $\%$ \\
\hline Housewife & & - & 10 & 500 & 9 & 45.0 & 19 & 52.8 \\
\hline Farmers & & & & - & 1 & 100.0 & 1 & 2.8 \\
\hline Employees & & & 9 & 69.2 & 4 & 30.8 & 13 & 36.1 \\
\hline Self-employed & & & & - & 2 & 10.0 & 2 & 5.6 \\
\hline Total & - & & 19 & & 16 & & 35 & 97.2 \\
\hline \multicolumn{9}{|c|}{ The level of women's knowledge (after) } \\
\hline \multirow[t]{2}{*}{ Occupation } & \multicolumn{2}{|l|}{ Good } & \multicolumn{2}{|l|}{ Enough } & \multicolumn{2}{|l|}{ Less } & \multicolumn{2}{|l|}{ Total } \\
\hline & Frequency (f) & $\%$ & Frequency (f) & $\%$ & Frequency (f) & $\%$ & Frequency (f) & $\%$ \\
\hline Housewife & 20 & 55.6 & & & & & 20 & 55.6 \\
\hline Farmers & 1 & 2.8 & & & & & 1 & 2.8 \\
\hline Employees & 13 & 36.1 & & & & & 13 & 36.1 \\
\hline Self-employed & 2 & 5.6 & & & & & 2 & 5.6 \\
\hline Total & 36 & & - & & - & & 36 & 100.0 \\
\hline
\end{tabular}

Table 5 Statistical analysis Wilcoxon signed-rank test

\begin{tabular}{|l|l|l|l|l|}
\hline \multirow{3}{*}{ After - Before } & \multicolumn{2}{|l|}{ Test Statistics } & After - Before \\
\cline { 2 - 6 } & Negative ranks & 1 & & -5.068 \\
\cline { 2 - 6 } & Positive ranks & 34 & Z & 0.00 \\
\cline { 2 - 5 } & Ties & 1 & Asymp. Sig. (2-tailed) & \\
\cline { 2 - 5 } & Total & 36 & & \\
\hline
\end{tabular}

the awareness of the women after the intervention with $p$-value $0.00(<0.05)$.

This study provided valuable information to the community, especially women. It was proven using a brochure with pictures that attracted attention, effectively conveying information, as we knew that in the present time, most people are comfortable using digital media because of its easy accessibility. Therefore, while meeting directly with communities using the brochure as a media tool, one could directly interact with a communicator if there were things that were misunderstood about the topic and more satisfaction could be derived by discussing things together. So, it was still effective to increase the knowledge of women about pap smear's ability to detect and prevent cervical cancer.

Age is an important aspect in influencing knowledge. With the increase in age of a person, it will be easier to make a change in the physical and psychological aspects, as the psychological aspects help developing the level of thinking to be more mature and adult. ${ }^{16}$ Based on the results of research, the level of knowledge of female respondents in the range of 51 to 55 years was good for one person (7.1\%), enough for five persons (35.7\%), and less for seven people (50\%). This result is in accordance with the one expressed by Wawan and Dewi, which also says that age plays an important role in influencing knowledge; the more the age of a person, the better is his or her knowledge. ${ }^{16}$

Education is guidance given to another person to understand a thing. One cannot deny that higher the education of a person, the more easily he or she receives information. On the contrary, if a person has a low level of education, it will inhibit the improvement of attitude of the person toward acceptance of the information and new values introduced. ${ }^{17,18}$

This study was not in accordance with the theory expressed by Supardi. Siswanto and Susila revealed that higher level of education aids in an easier absorption of knowledge. ${ }^{16,17}$ In this research, the knowledge of the women who attended high school was better compared with the women of undergraduate level, because before the health education intervention, it was found that the knowledge of female respondents at the high school level was good for one person (4.76\%), sufficient knowledge for 11 people $(52.4 \%)$, and less for nine people (42.9\%). Knowledge of female respondents at the bachelor's level did not exist for good, enough for seven people (77.8\%), and less for nine people (22.2\%). It is because one receives information through gadgets, and it is known that the average Indonesian citizen uses the cellphone $5.5^{18,19}$ hours per day and accesses the Internet for 4 to 7 hours per day (The Association of Internet Service 
Providers Indonesia).$^{19}$ Therefore, it depends on how the person wants to obtain the information, which is freely available on the Internet.

According to Polite and Beck, work is an activity or activities performed by people to achieve livelihood. The work environment can transform a person into a more experienced and better informed individual, directly or indirectly. Job factors can also influence knowledge. A working person will have better knowledge compared to someone who does not work, because work entails deriving information from others.

Results of research on the 36 female respondents in MTMH, as indicated in - Table 4, shows that women respondents' knowledge based on the point of view of occupation before the health education in terms of housewife was good for one person (5\%), enough for TEN people (50\%), and less for nine people (45\%). The knowledge of respondent women as farmers was good and enough for no one, and less for one person (100\%). The knowledge of respondents as employees either did not exist, enough for nine people (62.9\%), and less for four people (30.8\%). The knowledge of respondents as self-employed was good and enough for no one and less for two people (100\%). However, after health education, the overall knowledge of women turns out to be good, namely, knowledge of respondents as housewives is good for 20 people (100\%), enough and less nothing. The knowledge of women farmers was good for one person (100\%), enough and less for no one. The knowledge of female respondents as employees was good for 13 people (100\%), enough and less for no one. The knowledge of respondents as self-employed was good for two people (100\%), enough and less for no one.

This study result is not in accordance with what was said by Notoadmojo, which says that job factors also influence humans knowledge, as discussed earlier in this article. ${ }^{20}$ However, the results of this study showed a contradiction, because it was not forever that someone did not work or was less knowledgeable, and this study proved that women as housewives had good knowledge for one person (5\%), enough for ten people (50\%), and less for nine people (45\%), compared with female respondents who worked and had no proper knowledge before the health education. This was because the housewife was able to set the time and there was also a willingness to find out something which, in turn, would result in knowledge increase. Especially in this digital era, all the information is easily accessible due to the availability of smartphone and the price is still affordable, making it easier for someone to find the information required.

From the results of the study, which had 36 respondents in $\mathrm{MTMH}$, based on - Table 3, the knowledge of women was good for three people (8.3\%), enough for 12 people (33.3\%), and less for 21 people (58.3\%) before the health education. After health education, the number of women who were well knowledgeable rose to 30 people (83.3\%), enough for two people (5.6\%) and less for four people (11.1\%). It can be said there was a significant influence in increasing the knowledge of women about pap smear's ability to detect and prevent cervical cancer in MTMH as shown in - Table 5. The results of the test using statistical analysis and Wilcoxon signed-ranks test showed that $p$ value $<0.005$ where $p$ value $=0.00$, so it can be concluded that there is significant influence provision of health education on the level of knowledge among women about pap smear's ability to detect and prevent cervical cancer.

Some of the results of research conducted by previous researchers such as Erdin revealed that women's knowledge about the benefits of the HPV vaccine became better after health education in Turkey. ${ }^{21}$ Health education spread by Chinwe and Abigail ${ }^{22}$ and Olubodun et $\mathrm{a}^{23}$ mentioned that there was a change in the awareness level of secondary school teachers about knowledge, attitude, and practice of cervical cancer screening among secondary school teachers in Enugu state. The same was done by Ashtarian, who conducted research on the knowledge about cervical cancer and pap smear, and the factors that influence pap test screening among women, who possessed good knowledge about pap test screening and were willing to undergo screening. ${ }^{24}$ Knowledge is one of the factors that change the pattern and attitude of a person's behavior. The presence of health education can transform one's knowledge into a better direction. According to previous research by Winangsit, health education can change family knowledge about caring for asthma patients. Health education can change behavior or improve someone's knowledge about it. ${ }^{25}$ The previous research by Simanullang showed there was significant effect of health education on women's knowledge about cervical cancer at Bahorok village, North Sumatra. ${ }^{6}$

To conclude this study, there was a significant effect of health education in increasing the level of women's awareness about pap smear's ability to detect and prevent cervical cancer, thereby reducing women's mortality. Suggestions for further research are required to represent a greater number of respondents and a wider region.

\section{Conflict of Interest}

None declared.

\section{Acknowledgment}

The authors would like to thank the participants, and the assistants Lidya Tobing and Ruth Novella Napitupulu for participating in this study.

\section{References}

1 Mojica CM, Morales-Campos DY, Carmona CM, Ouyang Y, Liang Y. Breast, cervical, and colorectal cancer education and navigation: results of a community health worker intervention. Health Promot Pract 2016;17(3):353-363

2 Arbyn M, Anttila A, Jordan J, et al. European guidelines for quality assurance in cervical cancer screening. Second edition-summary document. Ann Oncol 2010;21(3):448-458

3 Saslow D, Solomon D, Lawson HW, et al; ACS-ASCCP-ASCP Cervical Cancer Guideline Committee. American Cancer Society, American Society for Colposcopy and Cervical Pathology, and American Society for Clinical Pathology screening guidelines for the prevention and early detection of cervical cancer. CA Cancer J Clin 2012;62(3):147-172

4 Karsa LV, Arbyn M, Vuyst H, et al. European guidelines for quality assurance in cervical cancer screening. Summary of the supplements on HPV screening and vaccination. Pappiloma Researh Journal Homepage 2015;1:22-31 
5 Putri. Meningkat, Kasus Kanker Serviks Baru di Indonesia. 2019. Available at: https://sains.kompas.com/. Accessed March 6, 2020

6 Simanullang RH. Impact of health education intervention on knowledge of cervical cancer prevention among women in Bahorok's Village, North Sumatra Indonesia. Belitung Nursing Journal 2018;4(6):591-595

7 Mishra GA, Pimple SA, Shastri SS. An overview of prevention and early detection of cervical cancers. Indian J Med Paediatr Oncol 2011;32(3):125-132

8 Rozi MF, Kiat Mudah Mengatasi Kanker Serviks. Yogyakarta: Aulia; 2013

9 Melissa CS, Davis CP. What is pap smear. 2017. Available at: https://www.emedicinehealth.com/. Accessed March 6, 2020

10 Moyer VA; U.S. Preventive Services Task Force. Screening for cervical cancer: U.S. Preventive Services Task Force recommendation statement. Ann Intern Med 2012;156(12):880891, W312

11 Polit DF, Beck CT. Nursing Research: Generating And Assessing Evidence For Nursing Practice. 9th ed. Philadelphia, PA: Lippincott Williams \& Wilkins; 2012

12 Batas A. Pengetahuan dan Sikap Wanita Mengenai Kanker Serviks dan Pap Smear Di RSU. Hermana Lembean Bulan November - Desember Tahun 2013. J E-Clinic 2014;2(1):13-15

13 Nursanti T, Pengaruh Pendidikan Kesehatan Tentang Kanker Serviks Terhadap Sikap Melakukan Pap smear Pada Akseptor IUD di Dusun Sanggrahan Maguwoharjo Depok Sleman. Naskah Publikasi PSIK STIKes 'Aisyiyah Yogjakarta; 2014

14 Gebrie MH, Belete MA, Lemlem SB, Woreta HK. Knowledge, preventive practice and associated factors of female nurses' towards cervical cancer in the selected government hospitals in Addis Ababa, Ethiopia. J Diabetes Metab 2015;6(7):1-8

15 Priya NS. Cervical cancer screening and classification using acoustic shadowing. International Journal of innovatibe Research in Computer and Communication Engineering 2013;1(8):1676-1679
16 Wawan, A, Dewi, M, Teori dan Pengukuran, Sikap, dan Perilaku Manusia. Yogyakarta: Numed; 2011

17 Supardi R, Metodologi Riset Keperawatan. Jakarta: Trans Info Media; 2013

18 YuniarM. Pengguna Internet Indonesia Habiskan 5,5 Jam Per Hari Dengan Ponsel. 2018 Available at: https://www.ekrut. com. Accessed March 6, 2020

19 SetiawanSRD. Berapa Lama Rata-rata Orang Indonesia Gunakan Internet dalam Sehari? 2019 Available at: https:// ekonomi.kompas.com. Accessed March 6, 2020

20 Notoatmodjo S SoekidjoMetodologi Penelitian Kesehatan. Jakarta: Rineta; 2014

21 Ilter E, Celik A, Haliloglu B, et al. Women's knowledge of pap smear test and human papillomavirus: acceptance of HPV vaccination to themselves and their daughters in an Islamic society. Int J Gynecol Cancer 2010;20(6):1058-1062

22 Chinwe ER, Abigail UR. Impact of health education on knowledge, attitude and practice of cervical cancer screening among secondary school teachers in Enugu state. J Womens Health Care 2015;4(4):1-7

23 Olubodun T, Odukoya OO, Balogun MR. Knowledge, attitude and practice of cervical cancer prevention, among women residing in an urban slum in Lagos, South West, Nigeria. Pan Afr Med J 2019;32:130

24 Ashtarian H, Mirzabeigi E, Mahmoodi E, Khezeli M. Knowledge about cervical cancer and pap smear and the factors influencing the pap test screening among women. Int J Community Based Nurs Midwifery 2017;5(2):188-195

25 Winangsit A, Maliya A, Sahuri Teguh K, Pengaruh Pendidikan Kesehatan Terhadap Perubahan Tingkat Pengetahuan Dan Sikap Keluarga Dalam Memberikan Perawatan Pada Penderita Asma Di Desa Sruni Musuk Boyolali. Yogyakarta: Universitas Muhammadiyah Surakarta; 2014 